\title{
Normalization of Raised Sodium Absorption and Raised Calcium-mediated Chloride Secretion by Adenovirus-mediated Expression of Cystic Fibrosis Transmembrane Conductance Regulator in Primary Human Cystic Fibrosis Airway Epithelial Cells
}

\author{
Larry G. Johnson, * Susan E. Boyles, ${ }^{*}$ James Wilson, ${ }^{\ddagger}$ and Richard C. Boucher* \\ *Cystic Fibrosis/Pulmonary Research and Treatment Center and the Department of Medicine, The University of North Carolina at \\ Chapel Hill, Chapel Hill, North Carolina 27599-7020; and ${ }^{\ddagger}$ The Institute for Human Gene Therapy, The University of Pennsylvania, \\ Philadelphia, Pennsylvania 19104
}

\begin{abstract}
Cystic fibrosis airway epithelia exhibit a spectrum of ion transport properties that differ from normal, including not only defective cAMP-mediated $\mathrm{Cl}^{-}$secretion, but also increased $\mathrm{Na}^{+}$absorption and increased $\mathrm{Ca}^{2+}$-mediated $\mathrm{Cl}^{-}$ secretion. In the present study, we examined whether adenovirus-mediated (Ad5) transduction of CFTR can correct all of these CF ion transport abnormalities. Polarized primary cultures of human $\mathrm{CF}$ and normal nasal epithelial cells were infected with Ad5-CBCFTR at an moi $\left(10^{4}\right)$ which transduced virtually all cells or Ad5-CMV lacZ as a control. Consistent with previous reports, Ad5-CBCFTR, but not Ad5CMV lacZ, corrected defective CF cAMP-mediated $\mathrm{Cl}^{-}$secretion. Basal $\mathrm{Na}^{+}$transport rates (basal $\mathrm{I}_{\mathrm{eq}}$ ) in $\mathrm{CF}$ airway epithelial sheets $\left(-78.5 \pm 9.8 \mu \mathrm{A} / \mathrm{cm}^{2}\right)$ were reduced to levels measured in normal epithelial sheets $\left(-30.0 \pm 2.0 \mu \mathrm{A} / \mathrm{cm}^{2}\right)$ by Ad5-CBCFTR $\left(-36.9 \pm 4.8 \mu \mathrm{A} / \mathrm{cm}^{2}\right)$, but not Ad5CMV lacZ $\left(-65.8 \pm 6.1 \mu \mathrm{A} / \mathrm{cm}^{2}\right)$. Surprisingly, a significant reduction in $\Delta I_{e q}$ in response to ionomycin, a measure of $\mathrm{Ca}^{2+}$-mediated $\mathrm{Cl}^{-}$secretion, was observed in CFTR-expressing (corrected) CF epithelial sheets $(-6.9 \pm 11.8 \mu \mathrm{A} /$ $\mathrm{cm}^{2}$ ) when compared to uninfected CF epithelial sheets $\left(-76.2 \pm 15.1 \mu \mathrm{A} / \mathrm{cm}^{2}\right)$. Dose response effects of Ad5CBCFTR on basal $\mathrm{Na}^{+}$transport rates and $\mathrm{Ca}^{2+}$-mediated $\mathrm{Cl}^{-}$secretion suggest that the mechanism of regulation of these two ion transport functions by CFTR may be different. In conclusion, efficient transduction of CFTR corrects hyperabsorption of $\mathrm{Na}^{+}$in primary $\mathrm{CF}$ airway epithelial cells and restores $\mathrm{Ca}^{2+}$-mediated $\mathrm{Cl}^{-}$secretion to levels observed in normal airway epithelial cells. Moreover, assessment of these ion transport abnormalities may represent important endpoints for testing the efficacy of gene therapy for cystic
\end{abstract}

Address correspondence to Larry G. Johnson, Division of Pulmonary Diseases and Critical Care Medicine, CB\#7020, 724 Burnett-Womack Bldg., The University of North Carolina at Chapel Hill, Chapel Hill, NC 27599-7020. Phone: 919-966-2531; FAX: 919-966-7524.

Received for publication 31 May 1994 and in revised form 16 November 1994.

J. Clin. Invest.

(c) The American Society for Clinical Investigation, Inc. 0021-9738/95/03/1377/06 \$2.00

Volume 95, March 1995, 1377-1382 fibrosis. (J. Clin. Invest. 1995. 95:1377-1382). Key words: cystic fibrosis • airway epithelia • sodium transport • adenovirus-mediated gene transfer • CFTR

\section{Introduction}

Cystic fibrosis (CF), ${ }^{1}$ the most common potentially lethal genetic disease in Caucasians, is caused by abnormal electrolyte transport in airway, sweat ductal, intestinal and pancreatic ductal epithelia $(1,2)$. The CF gene product, the cystic fibrosis transmembrane conductance regulator (CFTR), has been shown to be a cAMP-activated $\mathrm{Cl}^{-}$channel (3-5) and more recently to regulate the activity of other ion channels $(6,7)$. Complementation of the $\mathrm{CF} \mathrm{Cl}^{-}$permeability defect in vitro using adenovirus, retrovirus, vaccinia virus, and adeno-associated virus vectors strongly supports the notion that gene therapy for cystic fibrosis is feasible $(7-11)$. These studies have also spurred current clinical safety and efficacy gene transfer trials in the nasal cavity and lower airways of CF patients $(12,13)$.

All of the efforts in gene transfer for CF thus far have focused on correction of abnormal cAMP-mediated regulation of $\mathrm{Cl}^{-}$transport function (12). However, $\mathrm{CF}$ airway epithelia are also characterized by raised $\mathrm{Na}^{+}$transport $(14,15)$ and a raised alternative $\mathrm{Ca}^{2+}$-regulated $\mathrm{Cl}^{-}$secretory path (16-18). It has been speculated that abnormal $\mathrm{Na}^{+}$transport is central to the pathogenesis of CF airways disease (19), whereas the alternative $\mathrm{Ca}^{2+}$-mediated $\mathrm{Cl}^{-}$secretory path may be protective (18). Although not proven, both of these defects appear to reflect abnormal upregulation of channel expression/activity consequent to mutated CFTR $(15,16,18)$.

In the present study, we tested whether introduction of wildtype CFTR into CF airway epithelia normalizes raised $\mathrm{Na}^{+}$ absorption and raised $\mathrm{Ca}^{2+}$-mediated $\mathrm{Cl}^{-}$secretion in $\mathrm{CF}$ airway epithelia and consequently, whether these defects are potentially important endpoints of the efficacy of gene therapy.

1. Abbreviations used in this paper: $\Delta$, change; Ad5, adenovirus serotype 5; Ad5-CBCFTR, adenovirus serotype 5-based vector in which a CMV enhancer and $\beta$-actin promoter drive transcription of CFTR; Ad5CMV lacZ, Ad5-based vector in which a CMV enhancer/promoter drives transcription of the $\beta$-galactosidase gene; $\mathrm{CF}$, cystic fibrosis; CFTR, cystic fibrosis transmembrane conductance regulator; $\mathrm{Cl}_{\mathrm{a}}$, alternative chloride conductance; $\mathrm{I}_{\text {eq }}$, equivalent short circuit current; LacZ, $\beta$-galatosidase; $\mathrm{R}_{\mathrm{t}}$, transepithelial resistance; $\mathrm{V}_{\mathrm{t}}$, transepithelial potential difference. 


\section{Methods}

Cell culture. CF and normal nasal epithelial cells, isolated from surgical specimens by enzymatic digestion, were cultured as previously described (20). Cells were plated on permeable collagen substrates (surface area $\left.=0.16 \mathrm{~cm}^{2}\right)$ at supraconfluent densities, maintained in serumfree medium (Ham's F12) supplemented with seven growth factors (20) until day 4 in culture, then switched to $50 \%$ Swiss 3 T3-conditioned Dulbecco's modified Eagles medium with $4500 \mathrm{~g} / \mathrm{L}$ glucose plus $2 \%$ bovine calf serum diluted in serum-free medium. In dose effect relationship experiments, cells were grown on collagen substrates ( surface area $=0.071 \mathrm{~cm}^{2}$ ) under air liquid interface conditions (21) in the absence of cholera toxin.

Adenoviruses. Adenovirus vectors used in this study are replication defective viruses based on the human adenovirus serotype 5 (Ad5). Their construction and the preparation of viral stocks was as previously described (22). In this study, Ad5-CMV lacZ and Ad5-CBCFTR with titers of up to $10^{11} \mathrm{pfu} / \mathrm{ml}$ were utilized.

Viral infections. Primary CF airway epithelial sheets were infected at confluence (culture day 3 ) overnight $(\sim 18 \mathrm{~h})$ with $30 \mu$ l of either Ad5-CBCFTR or Ad5-CMV lac Z virus-containing medium at a multiplicity of infection (moi) of $10^{4}$, or sham infected. Cells were then washed and maintained in 50\% Swiss 3T3-conditioned medium for three additional days after infection. In the dose effect relationship experiments, cells were infected with $10 \mu \mathrm{l}$ of Ad5-CBCFTR (in view of the smaller surface area) at the following mois: $0,10^{-1}, 10^{0}, 10^{1}, 10^{2}$, $10^{3}$, and $10^{4}$

Bioelectric measurements. The transepithelial potential differences $\left(V_{t}\right)$ and resistances $\left(R_{t}\right)$ of all cultures were monitored (EVOM; World Precision Instruments, Inc., Sarasota, Florida) over days 4-6 in culture and the basal equivalent short circuit current $\left(\mathrm{I}_{\mathrm{eq}}\right)$ calculated. To characterize the $\mathrm{Cl}^{-}$transport function, cultures were mounted in a modified Ussing chamber interfaced to a current-voltage clamp (VCC600, Revision E; Physiologic Instruments, San Diego, CA) and superfused with Krebs-Ringer Bicarbonate solution, $\mathrm{pH} 7.4$ at $37^{\circ} \mathrm{C}$ aerated with $95 \%$ $\mathrm{O}_{2}-5 \% \mathrm{CO}_{2}$. The sequential bioelectric responses to $10^{-4} \mathrm{M}$ amiloride added to the luminal bath, luminal $\mathrm{Cl}^{-}$replacement with $0 \mathrm{mM} \mathrm{Cl}^{-}$ containing Ringer (gluconate substituted for chloride), $10 \mu \mathrm{M}$ forskolin, and $5 \mu \mathrm{M}$ ionomycin were measured.

Western blots. Western Blots were performed as previously described (23). Samples were harvested by direct application of $35 \mu \mathrm{l}$ urea buffer (67.5 mM Tris, pH 6.8; $7 \mathrm{M}$ urea; $160 \mathrm{mM}$ Dithiothreitol; $2 \%$ sodium dodecyl sulfate; $0.001 \%$ bromophenol blue) to the collagen substrate and stored at $-70^{\circ} \mathrm{C}$. Equal amounts of protein $(50 \mu \mathrm{g} /$ well $)$ were loaded onto a $4-15 \%$ polyacrylamide gel and electrophoresis was performed at $110 \mathrm{~V}$ for $60 \mathrm{~min}$. Blotting onto polyvinylidene difluoride (PVDF) membranes ( $0.2 \mu \mathrm{m}$ pore size; Bio Rad Labs., Hercules, CA) and immunodetection with anti-CFTR $\mathrm{COOH}$ terminus antibody was performed as previously described. T84 cell membranes were used as a marker of fully glycosylated CFTR

Immunohistochemistry. Epithelial sheets on collagen membrane supports were detached from their polycarbonate supports using a scapel, embedded in OCT compound (Miles, Inc., West Haven, CT), and frozen at $-70^{\circ} \mathrm{C}$. Frozen sections $(8-\mu \mathrm{m}$ thickness $)$ were cut on a Reichert Cryo-cut 1800 and stained for CFTR expression using a rabbit polyclonal anti-COOH terminus antibody $(\alpha 1468$, obtained from Dr. Jonathan Cohn, Duke University, Durham, NC) and a FITC-conjugated secondary antibody for immunofluorescent detection as previously described (24).

Statistics. All values are recorded as means \pm SE. Determination of statistical significance was performed using the student's $t$ test. Significance was defined as $p<0.05$. An analysis of variance (ANOVA) was used to detect statistical significance in the dose effect relationship experiments.

\section{Results}

Characterization of CFTR protein expression. As shown in Fig. $1 A$, Western blot analysis revealed that CFTR protein was expressed in high levels in CF epithelial sheets infected with Ad5-CBCFTR, while CFTR was barely detectable in uninfected sheets or $\beta$-galactosidase (LacZ)-expressing epithelial sheets. Note that two bands were seen in whole cell lysates of CF cells expressing transduced CFTR: the fully glycosylated or mature form corresponding to a band at $180 \mathrm{kD}$ and the core glycosylated protein at $\sim 140 \mathrm{kD}$. T84 cell membranes, used as a marker of CFTR, exhibited a major band at $180 \mathrm{kD}$, which was expected since the fully glycosylated form would be primarily expressed in the membrane. CFTR protein could not be clearly detected in cultured primary normal airway epithelial cells (Fig. $1 \mathrm{~A}$, lane 6), although these cells exhibit normal $\mathrm{Cl}^{-}$transport function. Shown in Fig. $1 B$ is immunohistochemistry for CFTR in corrected (Ad5-CBCFTR-infected) CF epithelial sheets. Note that staining is present in all cells facing the lumen in corrected sheets. Moreover, both apical and cytoplasmic staining patterns are present consistent with high level expression of CFTR. In contrast, no immunohistochemical staining for CFTR protein is detected in the Ad5-CBCFTR-infected CF epithelial sheets stained with secondary antibody alone (Fig. $1 C$ ).

Characterization of basal $\mathrm{Na}^{+}$transport rates. Previous radioisotopic flux data have shown that basal $\mathrm{I}_{\text {eq }}$ equals net $\mathrm{Na}^{+}$ absorption in cultured human airway epithelia (15). Because basal $I_{\text {eq }}$ generally peaks on culture day 6 , we monitored the basal $\mathrm{I}_{\mathrm{eq}}$ in primary $\mathrm{CF}$ and normal airway cells daily from days 4-6 in culture. The expected pattern of a two- to threefold greater $\mathrm{I}_{\mathrm{eq}}$ in uninfected $\mathrm{CF}$ cells as compared to uninfected normal cells was observed on days 5 and 6 in culture (Fig. 2 $A$ ). In contrast, the basal $\mathrm{I}_{\mathrm{eq}}$ in corrected CF epithelial sheets was similar to the basal $I_{\text {eq }}$ measured in the normal epithelial sheets, consistent with correction of $\mathrm{Na}^{+}$transport (Fig. $2 \mathrm{~B}$ ). An approximately twofold reduction in the mean basal $\mathrm{I}_{\mathrm{eq}}$ in CFTR-expressing CF epithelial sheets (corrected cells) was measured three days after infection $\left(-36.9 \pm 4.8 \mu \mathrm{A} / \mathrm{cm}^{2}\right.$; Fig. $2 B$ ) when compared to uninfected $\left(-78.5 \pm 9.8 \mu \mathrm{A} / \mathrm{cm}^{2}\right.$; Fig. $2 A)$ or LacZ-expressing CF cells $\left(-65.8 \pm 6.1 \mu \mathrm{A} / \mathrm{cm}^{2}\right.$; Fig. 2 $C)$. The expression of $\mathrm{LacZ}$ or CFTR by Ad5 vectors did not alter the rate of $\mathrm{Na}^{+}$transport in normal airway epithelial cultures (compare Fig. 2, $A-C$ ).

Characterization of basal $\mathrm{Cl}^{-}$transport function. We studied a series of CF and normal epithelial sheets in Ussing chambers to characterize their $\mathrm{Cl}^{-}$secretory capacity. Shown in Fig. $3 A$ is the percent inhibition of $\mathrm{I}_{\mathrm{eq}}$ by the $\mathrm{Na}^{+}$channel blocker, amiloride. Amiloride in airway epithelia both abolishes $\mathrm{Na}^{+}$ transport and induces a driving force for $\mathrm{Cl}^{-}$secretion (15). Thus, the percent inhibition of $\mathrm{I}_{\mathrm{eq}}$ by amiloride reflects in part, the ability of the apical membrane to conduct transepithelial $\mathrm{Cl}^{-}$ion flows. Amiloride inhibited basal $\mathrm{I}_{\text {eq }}$ in uninfected and LacZ-expressing CF cells $\sim 90 \%$, consistent with the absence of a significant basal $\mathrm{Cl}^{-}$conductance. In contrast, a significantly lower percent inhibition of $\mathrm{I}_{\mathrm{eq}}$ occurred post-amiloride in CFTR-expressing CF cells $(61.8 \pm 4.8 \%)$, consistent, in part, with the expression of a basal $\mathrm{Cl}^{-}$conductance.

The change in transepithelial potential difference with replacement of luminal $\mathrm{Cl}^{-}$by gluconate $\left(\Delta \mathrm{V}_{\mathrm{tCl}^{-}}{ }^{-}\right.$Free $)$reflects in part, the $\mathrm{Cl}^{-}$permselectivity of the apical membrane. The small change $(\Delta) \mathrm{V}_{\mathrm{tCl}^{-}}$Free measured in uninfected $(-1.7 \pm 2.0 \mathrm{mV})$ and LacZ-expressing $(-4.3 \pm 1.6 \mathrm{mV}) \mathrm{CF}$ cells is consistent with the absence of a significant apical membrane $\mathrm{Cl}^{-}$conductance (Fig. $3 \mathrm{~B}$ ). A significantly more negative $\Delta \mathrm{V}_{\mathrm{t} \mathrm{Cl}}^{-}$Free was detected in CFTR-expressing CF cells $(-36.2 \pm 3.6 \mathrm{mV})$, sug- 

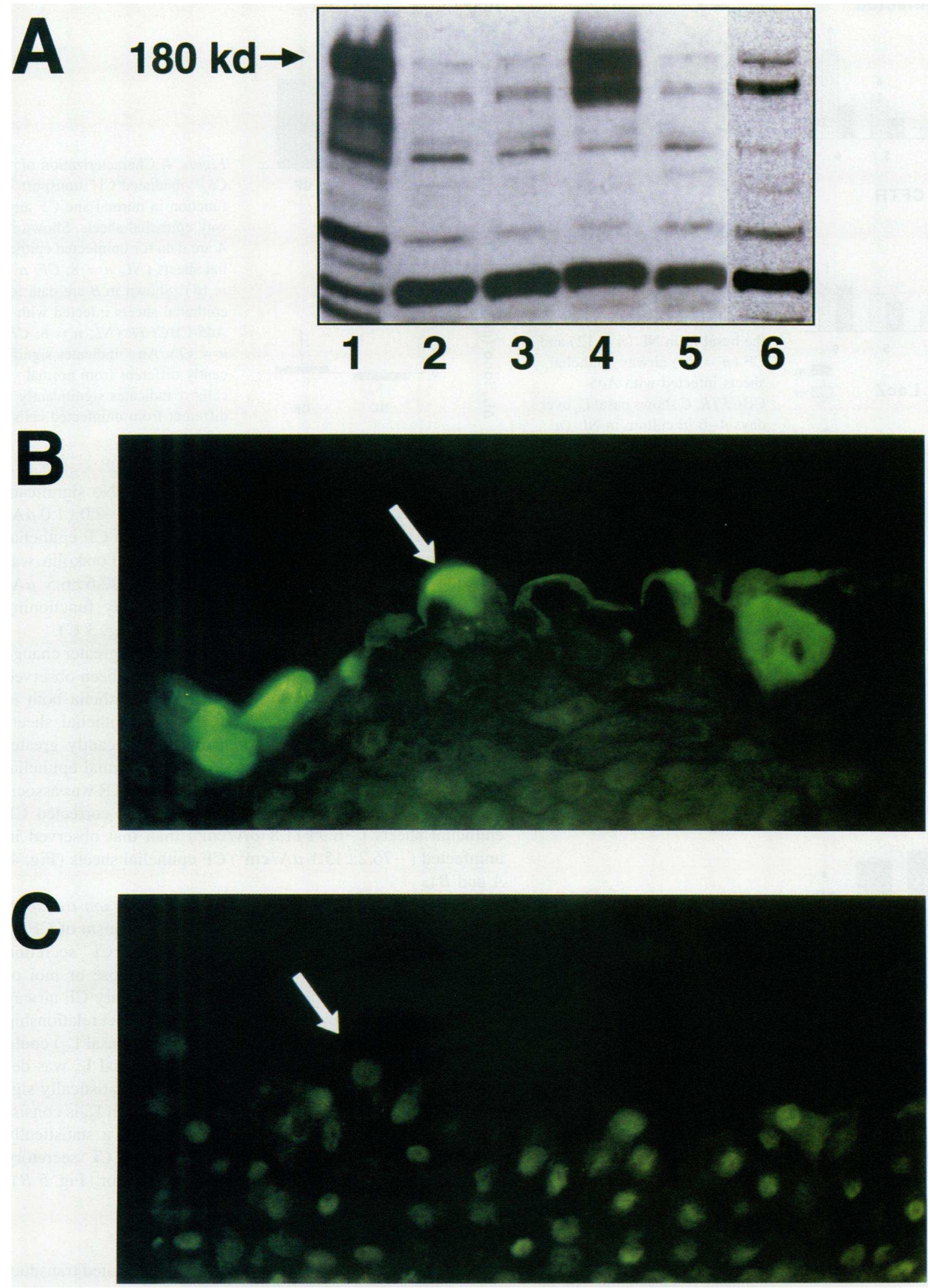

Figure 1. Characterization of CFTR expression in CF and normal epithelial sheets. $(A)$ Western blot of CF airway cells from epithelial sheets infected with either Ad5-CBCFTR or Ad5-CMV lacZ using an anti-CFTR COOH terminus antibody. UNIF represents uninfected CF cells. LacZ represents CF epithelial cells three days after infection with Ad5-CMV lacZ. CFTR represents CF cells infected with Ad5-CBCFTR three days after infection. Lanes are as follows: 1, T84; 2, UNIF; 3, LacZ; 4, CFTR; and 5, LacZ. Shown in lane 6 are uninfected cultured primary normal airway epithelial cells. $B$ shows immunohistochemical detection of CFTR using an anti-COOH terminus polyclonal antibody ( $\alpha 1468)$ and a fluoresceinconjugated secondary antibody in an Ad5-CBCFTR-infected (corrected) CF epithelial sheet. The arrow points out a cell on the lumen expressing CFTR identified by the green fluorescent staining. Shown in $C$ is a corrected CF epithelial sheet stained with secondary, but no primary antibody. Note the absence of CFTR staining on cells facing the lumen depicted by the arrow. 

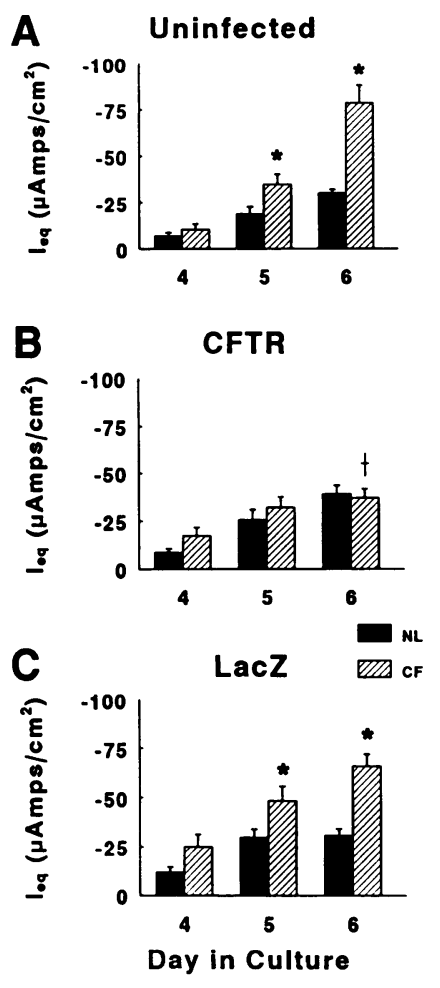

Figure 2. Characterization of basal $\mathrm{Na}^{+}$transport rates. $A$ shows basal $\mathrm{I}_{\mathrm{eq}}$ over days 4-6 in culture in uninfected NL ( $n$ $=10)$ and $\mathrm{CF}(n=11)$ airway epithelial sheets. Shown in $B$ is the basal $\mathrm{I}_{\mathrm{eq}}$ in NL $(n=12)$ and CF $(n=20)$ airway epithelial sheets infected with Ad5CBCFTR. $C$ shows basal $\mathrm{I}_{\mathrm{eq}}$ over days 4-6 in culture in NL ( $n$ $=11)$ and $\mathrm{CF}(n=15)$ epithelial sheets infected with Ad5CMV lacZ. * indicates significantly different from normal epithelial sheets. $\dagger$ indicates significantly different from uninfected epithelial sheets.

gesting the induction of a large apical membrane permeability in the corrected cells (Fig. $3 B$ ).

Characterization of cAMP-mediated $\mathrm{Cl}^{-}$transport function. The change in short circuit current induced by the cAMP-mediated agonist forskolin ( $\left.\Delta \mathrm{I}_{\mathrm{eq} \text { Forskolin }}\right)$, was used to assess regula-
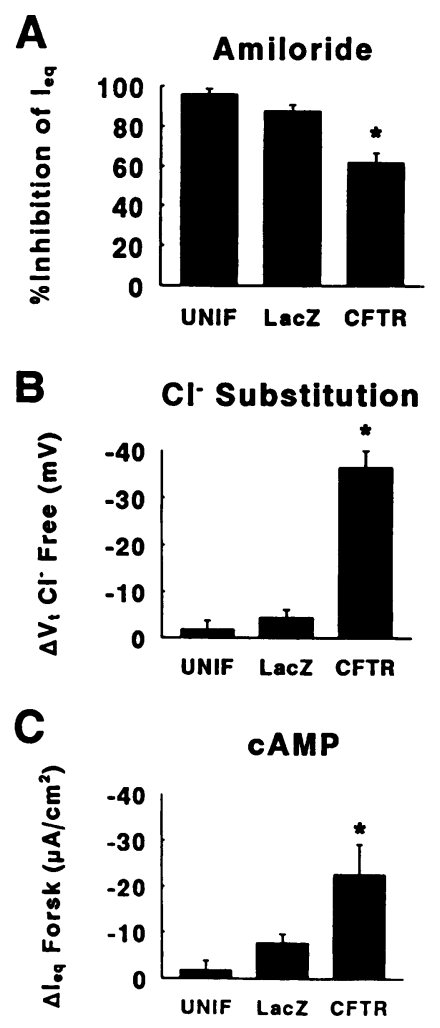

Figure 3. Characterization of basal and cAMP-mediated $\mathrm{Cl}^{-}$ transport function in $\mathrm{CF}$ airway epithelial sheets. $A$ displays the percent inhibition of $\mathrm{I}_{\mathrm{eq}}$ by amiloride. $B$ shows the change in transepithelial voltage with luminal chloride substitution $\left(\Delta \mathrm{V}_{\mathrm{tCl}^{-}}{ }^{-}\right.$ree $)$. Shown in $C$ is the change in $\mathrm{I}_{\mathrm{eq}}$ in response to the cAMP-mediated agonist, forskolin $\left(\Delta \mathrm{I}_{\text {eq Forskolin }}\right)$. The responses displayed were sequential, ie., amiloride, added to the luminal bath, was followed by luminal $\mathrm{Cl}^{-}$substitution ( still in the presence of amiloride), and the subsequent addition of forskolin. * indicates significantly different from uninfected cells. UNIF, $n=5 ;$ LacZ, $n=9$; CFTR, $n=10$.
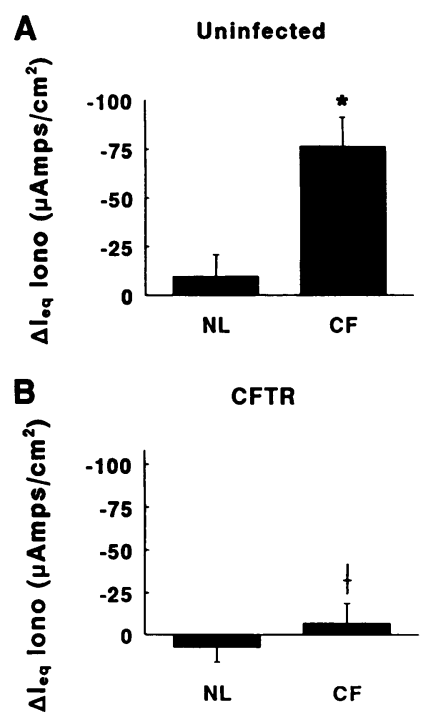

Figure 4. Characterization of $\mathrm{Ca}^{2+}$-mediated $\mathrm{Cl}^{-}$transport function in normal and CF airway epithelial sheets. Shown in $A$ are data for uninfected epithelial sheets $(N L, n=8 ; C F, n$ $=16$ ). Shown in $B$ are data for epithelial sheets infected with Ad5-CBCFTR ( $N L, n=6 ; C F$, $n=17)$. An $*$ indicates significantly different from normal cells. + indicates significantly different from uninfected cells.

tion of the apical membrane $\mathrm{Cl}^{-}$conductance. No significant change in $\Delta \mathrm{I}_{\mathrm{eq}}$ Forskolin was detected in uninfected $(-2.0 \pm 1.0 \mu \mathrm{A} /$ $\mathrm{cm}^{2}$ ) and LacZ-expressing $\left(-7.6 \pm 2.0 \mu \mathrm{A} / \mathrm{cm}^{2}\right) \mathrm{CF}$ epithelial sheets. In contrast, a significantly greater $\Delta \mathrm{I}_{\mathrm{eq}}$ Forskolin was detected in the CFTR-expressing CF cells $(-22.6 \pm 6.5 \mu \mathrm{A} /$ $\mathrm{cm}^{2}$ ), consistent with the induction of normally functioning CFTR $\mathrm{Cl}^{-}$channels in the apical membrane (Fig. $3 C$ ).

$\mathrm{Ca}^{2+}$-mediated $\mathrm{Cl}^{-}$secretion. A consistently greater change in $\mathrm{I}_{\mathrm{eq}}$ in response to $\mathrm{Ca}^{2+}$-mediated agonists has been observed in CF epithelia compared to normal airway epithelia both in vitro and in vivo $(16,17)$. Uninfected $\mathrm{CF}$ epithelial sheets responded to ionomycin $(5 \mu \mathrm{M})$ with a significantly greater $\Delta \mathrm{I}_{\text {eq ionomycin }}$ than that measured in uninfected normal epithelial sheets (Fig. $4 \mathrm{~A}$ ). Surprisingly, expression of CFTR was associated with a significantly smaller $\Delta \mathrm{I}_{\text {eq ionomycin }}$ in corrected CF epithelial sheets $\left(-6.9 \pm 11.8 \mu \mathrm{A} / \mathrm{cm}^{2}\right)$ than that observed in uninfected $\left(-76.2 \pm 15.1 \mu \mathrm{A} / \mathrm{cm}^{2}\right) \mathrm{CF}$ epithelial sheets (Fig. 4, $A$ and $B$ ).

Dose effect relationship of Ad5-CBCFTR on ion transport function. To begin to address the issue of mechanism of CFTR regulation of $\mathrm{Na}^{+}$transport and $\mathrm{Ca}^{2+}$-mediated $\mathrm{Cl}^{-}$secretion by CFTR, we tested the effect of increasing dose or moi of Ad5-CBCFTR on ion transport function in primary CF airway epithelial cells. As shown in Fig. $5 \mathrm{~A}$, no dose effect relationship of Ad5-CBCFTR on basal $\mathrm{Na}^{+}$transport rates (basal $\mathrm{I}_{\mathrm{eq}}$ ) could be demonstrated. A twofold reduction in the basal $\mathrm{I}_{\mathrm{cq}}$ was detected at the highest moi of $10^{4}$, although not statistically significant by an ANOVA. However, the reduction in $\mathrm{I}_{\mathrm{eq}}$ is consistent with data presented in Fig. 2. In contrast, a statistically significant dose-related decline in $\mathrm{Ca}^{2+}$-mediated $\mathrm{Cl}^{-}$secretory current was detected with increasing moi of vector (Fig. $5 B$ ).

\section{Discussion}

In the present study, we utilized adenovirus-mediated transduction of CFTR into CF airway epithelia to examine the effects of CFTR on the $\mathrm{Na}^{+}$absorptive pathway. We used a high moi in this study to ensure maximal gene transfer efficiency, because it was designed to test the concept that $\mathrm{Na}^{+}$transport is a correctable defect. The Western blot data (Fig. $1 A$ ) presented indicate a high level expression of CFTR in corrected, but not 


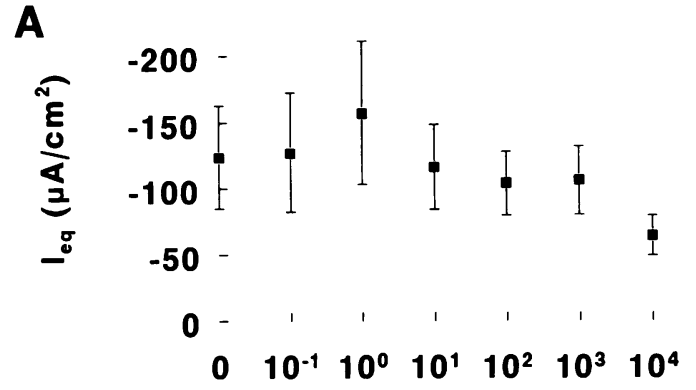

B

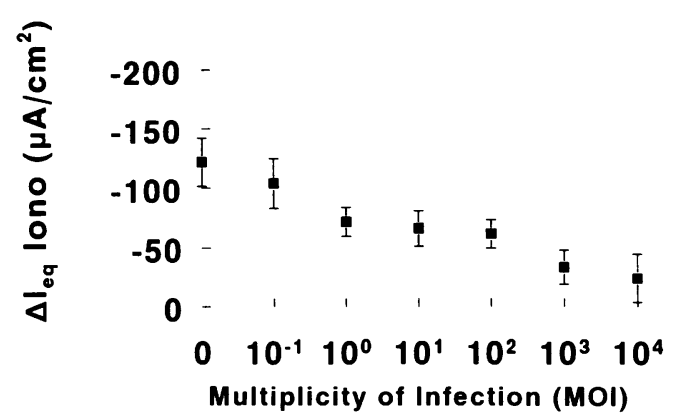

Figure 5. Dose Response of Ad5-CBCFTR on $\mathrm{Na}^{+}$transport and $\mathrm{Ca}^{2+}$ mediated $\mathrm{Cl}^{-}$secretion in primary CF epithelia. Shown in $A$ is the effect of increasing doses (moi) on basal $\mathrm{I}_{\mathrm{eq}}\left(\mathrm{Na}^{+}\right.$transport). $B$ shows the effect of increasing moi on the change in current with ionomycin. $n$ $=9-12$ epithelial cell cultures for each dose of vector.

uninfected or LacZ-expressing CF tissues. Immunohistochemistry for CFTR (Fig. $1 B$ ) not only confirms the western blot data, but also demonstrates that every cell facing the airway lumen has been transduced in Ad5-CBCFTR-infected CF epithelial sheets. Consistent with efficient transduction of CFTR, indices of $\mathrm{Cl}^{-}$transport in CFTR-expressing tissues demonstrated restoration of basal and cAMP-mediated $\mathrm{Cl}^{-}$secretion when compared to uninfected or LacZ-expressing CF epithelial sheets as reported by others (Fig. 3 ).

Using this strategy, we found that the $\mathrm{CF} \mathrm{Na}{ }^{+}$transport defect was corrected by introduction of wild-type CFTR. The rate of $\mathrm{Na}^{+}$transport (basal $\mathrm{I}_{\mathrm{eq}}$ ) was downregulated in CFTRexpressing $\mathrm{CF}$ epithelial sheets (Fig. $2 \mathrm{~B}$ ) to rates similar to those of normal epithelial sheets. This effect appears to be specific to CFTR transduction and not vector exposure, because Ad5-CMV lacZ infection had no significant effect on basal $\mathrm{I}_{\mathrm{eq}}$ (Fig. $2 C$ ). Moreover, additional CFTR does not further downregulate $\mathrm{Na}^{+}$transport in normal cells.

Previous in vitro and in vivo studies suggest that the nonCFTR-mediated or alternative apical membrane $\mathrm{Cl}^{-}$conductance $\left(\mathrm{Cl}_{\mathrm{a}}\right)$ is increased in human $\mathrm{CF}$ airway epithelia when compared to normal airway epithelia $(16,17)$. Studies in the $\mathrm{CF}(-/-)$ mouse model demonstrated that $\mathrm{Ca}^{2+}$-mediated $\mathrm{Cl}^{-}$ secretion occurs through this alternative pathway and that the $\mathrm{Cl}_{\mathrm{a}}$ may be protective (18). In the present study, we found that adenovirus-mediated transduction of CFTR resulted in functional reduction of $\mathrm{Ca}^{2+}$-mediated $\mathrm{Cl}^{-}$secretion in $\mathrm{CF}$ epithelial sheets. This decrease in the $\mathrm{Ca}^{2+}$-mediated $\mathrm{Cl}^{-}$secretory response in corrected tissues is consistent with restoration of $\mathrm{Cl}_{\mathrm{a}}$ pathway to normal levels.

Because the $\mathrm{Na}^{+}$channel subunits have only recently been cloned $(25,26)$ and $\mathrm{Cl}_{\mathrm{a}}$ has not yet been cloned, it is difficult to explain the mechanism by which CFTR exerts effects on both $\mathrm{Na}^{+}$transport and $\mathrm{Cl}_{\mathrm{a}}$ activity. To gain some insight into potential mechanisms, the dose effect relationships between vector moi and correction of $\mathrm{Na}^{+}$transport rates and $\mathrm{Cl}_{\mathrm{a}}$ activity were examined (Fig. 5 ). $\mathrm{Na}^{+}$transport was not corrected until high mois were employed, consistent with a requirement for transduction of most cells in the monolayer (Fig. 1). This relationship suggests that correction of $\mathrm{Na}^{+}$transport is a linear function of CFTR transfer efficiency, and that little amplification of correction is achieved, contrasting with studies in which correction of as few as $6-10 \%$ of cells restored cAMP-mediated $\mathrm{Cl}^{-}$transport to normal (27). The simplest hypothesis is that direct interactions of CFTR protein and $\mathrm{Na}^{+}$channel protein account for this phenomenon, and this interaction must occur in each transduced cell to normalize $\mathrm{Na}^{+}$channel function. This hypothesis is consistent with microelectrode and patch clamp data $(15,28)$, which indicate that the abnormally raised $\mathrm{CF}$ $\mathrm{Na}^{+}$transport rates reflect upregulation of apical membrane $\mathrm{Na}^{+}$entry, as manifested by an increase in $\mathrm{Na}^{+}$channel open probability $\left(\mathrm{P}_{\mathrm{o}}\right)$. The ability of CFTR to regulate the functional activity of an independent ion channel, the outwardly rectifying chloride channel (ORCC), provides support for such a mechanism $(6,7)$.

In contrast, $\mathrm{Cl}_{\mathrm{a}}$ function was reduced at low mois, implying that amplification of low efficiency CFTR transduction occurred. However, the decrease in $\mathrm{Ca}^{2+}$-mediated $\mathrm{Cl}^{-}$secretion $\left(\mathrm{Cl}_{\mathrm{a}}\right)$ with increasing moi, as compared to an increase in cAMPmediated $\mathrm{Cl}^{-}$secretion (29), indicates that $\mathrm{Cl}^{-}$movement through gap junctions (27) is not the mechanism responsible for the amplification of the $\mathrm{Cl}_{\mathrm{a}}$ response. We speculate that this observation might be explained by an inverse relationship between expression of CFTR and $\mathrm{Cl}_{\mathrm{a}}$, as has been reported for CFTR and multidrug resistance (MDR) (30), or that other unknown factors regulating expression of $\mathrm{Cl}_{\mathrm{a}}$ may be involved.

In summary, efficient expression of wild-type CFTR by Ad5-mediated gene transfer reduces raised $\mathrm{Na}^{+}$transport rates to levels observed in normal epithelial cell sheets. Hence, CFTR function is closely linked to regulation of $\mathrm{Na}^{+}$transport permitting, in theory, correction of both defective $\mathrm{Cl}^{-}$secretion and $\mathrm{Na}^{+}$hyperabsorption by gene therapy. Correction of defective cAMP-mediated $\mathrm{Cl}^{-}$transport and $\mathrm{Na}^{+}$hyperabsorption in this study was also associated with a reversal of the reciprocal relationship between functioning CFTR and $\mathrm{Ca}^{2+}$-mediated $\mathrm{Cl}^{-}$ secretion. Because defects other than cAMP-mediated $\mathrm{Cl}^{-}$ transport may be important in pathogenesis of airways disease, these results suggest that future gene therapy efforts should develop protocols that measure all aspects of CF dysfunction and correction.

\section{Acknowledgments}

The authors wish to thank Dr. J. Cohn, Dr. R. Pickles, Dr. W. Huang, Dr. H. Ye, Ms. K. Moore, Ms. J. Morris, and Ms. H. Suchindran for their assistance with this project.

This work was supported in part by the National Institutes of Health grant HL42384 from the National Heart, Lung, and Blood Institute.

\section{References}

1. Boat, T. F., M. J. Welsh, and A. L. Beaudet. 1989. Cystic fibrosis. In The Metabolic Basis of Inherited Disease. C. R. Scriver, A. L. Beaudet, W. S. Sly, and D. Valle, editors. McGraw Hill, New York. 2649-2680. 
2. Quinton, P. 1990. Cystic fibrosis: a disease in electrolyte transport. FASEB (Fed. Am. Soc. Exp. Biol.) J. 4:2709-2717.

3. Anderson, M. P., R. J. Gregory, S. Thompson, D. W. Souza, S. Paul, R. C. Mulligan, A. E. Smith, and M. J. Welsh. 1991. Demonstration that CFTR is a chloride channel by alteration of its anion selectivity. Science (Wash. DC). 253:202-205.

4. Bear, C. E., F. Duguay, A. L. Naismith, N. Kartner, J. W. Hanrahan, and J. R. Riordan. 1991. $\mathrm{Cl}^{-}$channel activity in Xenopus oocytes expressing the cystic fibrosis gene. J. Biol. Chem. 266:19142-19145.

5. Kartner, N., J. W. Hanrahan, T. J. Jensen, A. L. Naismith, S. Z. Sun, C. A Ackerley, E. F. Reyes, L.-C. Tsui, J. M. Rommens, C. E. Bear, and J. R. Riordan. 1991. Expression of the cystic fibrosis gene in non-epithelial invertebrate cells produces a regulated anion conductance. Cell. 64:681-691.

6. Gabriel, S., L. L. Clarke, R. C. Boucher, and M. J. Stutts. 1993. CFTR and outward rectifying chloride channels are distinct proteins with a regulatory relationship. Nature (Lond.). 363:263-266.

7. Egan, M., T. Flotte, S. Afione, R. Solow, P. L. Zeitlin, B. J. Carter, and W. B. Guggino. 1992. Defective regulation of outwardly rectifying $\mathrm{Cl}^{-}$channels by protein kinase A corrected by insertion of CFTR. Nature (Lond.). 358:581584.

8. Rosenfeld, M. A., K. Yoshimura, B. C. Trapnell, K. Yoneyama, E. R Rosenthal, W. Dalemans, M. Fukayama, J. Bargon, L. E. Stier, L. StratfordPerricaudet et al. 1992. In vivo transfer of the human cystic fibrosis transmembrane conductance regulator gene to the airway epithelium. Cell. 68:143-155.

9. Drumm, M. L., H. A. Pope, W. H. Cliff, J. M. Rommens, S. A. Marvin, L.-C. Tsui, F. S. Collins, R. A. Frizzell, and J. M. Wilson. 1990. Correction of the cystic fibrosis defect in vitro by retrovirus-mediated gene transfer. Cell. 62:1227-1233.

10. Rich, D. P., M. P. Anderson, R. J. Gregory, S. H. Cheng, S. Paul, D. M Jefferson, J. D. McCann, K. W. Klinger, A. E. Smith, and M. J. Welsh. 1990. Expression of the cystic fibrosis transmembrane conductance regulator corrects defective chloride channel regulation in cystic fibrosis airway epithelial cells. Nature (Lond.). 347:358-363.

11. Flotte, T. R., S. A. Afione, R. Solow, M. L. Drumm, D. Markakis, W. B Guggino, P. L. Zeitlin, and B. J. Carter. 1993. Expression of the cystic fibrosis transmembrane conductance regulator from a novel adeno-associated virus promoter. J. Biol. Chem. 268:3781-3790.

12. Zabner, J., L. A. Couture, R. J. Gregory, S. M. Graham, A. E. Smith, and M. J. Welsh. 1993. Adenovirus-mediated gene transfer transiently corrects the chloride transport defect in nasal epithelia of patients with cystic fibrosis. Cell. 75:207-216.

13. Boucher, R. C., M. R. Knowles, L. G. Johnson, J. C. Olsen, R. Pickles, J. M. Wilson, J. Engelhardt, Y. Yang, and M. Grossman. 1994. Gene therapy for cystic fibrosis using E1-deleted adenovirus: a phase I trial in the nasal cavity. Human Gene Therapy. 5:615-639.

14. Boucher, R. C., M. J. Stutts, M. R. Knowles, L. Cantley, and J. T. Gatzy. 1986. $\mathrm{Na}^{+}$transport in cystic fibrosis respiratory epithelia: abnormal basal rate and response to adenylate cyclase activation. J. Clin. Invest. 78:1245-1252.

15. Willumsen, N. J., and R. C. Boucher. 1991. Transcellular sodium transport in cultured cystic fibrosis human nasal epithelium. Am. J. Physiol. 261:C332C341.
16. Willumsen, N. J., and R. C. Boucher. 1989. Activation of an apical Clconductance by $\mathrm{Ca}^{2+}$ ionophores in cystic fibrosis airway epithelia. Am. J. Physiol. 256:C226-C233.

17. Knowles, M. R., L. L. Clarke, and R. C. Boucher. 1991. Activation by extracellular nucleotides of chloride secretion in the airway epithelial of patients with cystic fibrosis. N. Engl. J. Med. 325:533-538.

18. Clarke, L. L., Grubb, B. R., Yankaskas, J. R., C. U. Cotton, A. McKenzie, and R. C. Boucher. 1994. Relationship of a nonCFTR-mediated chloride conductance to organ-level disease in CFTR $(-/-)$ mice. Proc. Natl. Acad. Sci. USA. 91:479-483.

19. Knowles, M. R., N. L. Church, W. E. Waltner, J. R. Yankaskas, P. Gilligan, M. King, L. J. Edwards, R. W. Helms, and R. C. Boucher. 1990. A pilot study of aerosolized amiloride for the treatment of cystic fibrosis lung disease. $N$. Engl. J. Med. 322:1189-1194.

20. Yankaskas, J. R., C. U. Cotton, M. R. Knowles, J. T. Gatzy, and R. C Boucher. 1985. Culture of human nasal epithelial cells on collagen matrix supports. Am. Rev. Respir. Dis. 132:1281-1287.

21. Johnson, L. G., K. G. Dickman, K. L. Moore, L. J. Mandel, and R. C. Boucher. Enhanced $\mathrm{Na}^{+}$transport in an air-liquid interface culture system. 1993. Am. J. Physiol. 264:L560-565.

22. Englelhardt, J. F., Y. Yang, L. D. Stratford-Perricaudet, E. D. Allen, K Kozarsky, M. Perricaudet, J. R. Yankaskas, and J. M. Wilson. 1993. Direct gene transfer of human CFTR into human bronchial epithelia of xenografts with E1deleted adenoviruses. Nature Genetics. 4:27-34.

23. Sarkadi, B., D. Bauzon, W. R. Huckle, H. S. Earp, A. Berry, H. Suchindran, E. M. Price, J. C. Olsen, R. C. Boucher, and G. A. Scarborough. 1992. Biochemica characterization of the cystic fibrosis transmembrane conductance regulator in normal and cystic fibrosis epithelial cells. J. Biol. Chem. 267:2087-2095.

24. Englehardt, J. F., J. R. Yankaskas, S. A. Ernst, Y. Yang, C. R. Marino, R. C. Boucher, J. A. Cohn, and J. M. Wilson. 1992. Submucosal glands are the predominant site of CFTR expression in the human bronchus. Nature Genet. 2:240-248.

25. Canessa, C. M., J.-D. Horisberger, and B. C. Rossier. 1993. Epithelial sodium channel related to proteins involved in neurodegeneration. Nature (Lond.). 361:467-470.

26. Canessa, C. M., L. Schild, G. Buell, B. Thorens, I. Gautschi, J.-D. Horisberger, and B. C. Rossier. 1994. Amiloride sensitive epithelial $\mathrm{Na}^{+}$channel is made of three homologous subunits. Nature (Lond.). 367:463-466.

27. Johnson, L. G., J. C. Olsen, B. Sarkadi, K. L. Moore, R. Swanstrom, and R. C. Boucher. 1992. Efficiency of gene transfer for restoration of normal airway epithelial function in cystic fibrosis. Nature Genet. 2:21-25.

28. Chinet, T. C., J. M. Fullton, J. R. Yankaskas, R. C. Boucher, and M. J. Stutts. 1994. Mechanism of sodium hyperabsorption in cultured cystic fibrosis nasal epithelium: a patch-clamp study. Am. J. Physiol. 266:C1061-C1068.

29. Grubb, B. R., R. J. Pickles, H. Ye, J. R. Yankaskas, R. N. Vick, J. F. Engelhardt, J. M. Wilson, L. G. Johnson, and R. C. Boucher. 1994. Inefficient gene transfer by adenovirus vector to cystic fibrosis airway epithelia of mice and humans. Nature (Lond.). 371:802-805.

30. Breuer, W., I. N. Slotki, D. A. Ausciello, and I. Z. Cabantchik. 1993. Induction of multidrug resistance downregulates the expression of CFTR in colon epithelial cells. Am. J. Physiol. 265:C1711-C1715. 